IJMS 18 (1), 135-154 (2011)

\title{
JOB CHARACTERISTICS: WHAT CAN WE LEARN FROM THE EAST?
}

\author{
MOHD AWANG IDRIS* \\ MAUREEN F. DOLLARD \\ ANTHONY H WINEFIELD \\ School of Psychology, \\ University of South Australia \\ *Department of Anthropology \& Sociology \\ Universiti Malaya, Malaysia
}

\begin{abstract}
Since being introduced in 2000, the Job Demands and Resources (JD-R) model (Demerouti, Bakker, Nachreiner \& Schaufeli, 2000) has been studied extensively in various Western countries. Although the JD-R proposition is not proscriptive about specific demands and resource variables, scholars have used common variables as demands (e.g. workloads, deadlines), and as resources (e.g. support). The question is whether the common variables in the $J D-R$ model that had their origins in Western formulations are applicable in developing countries. In this paper, based on grounded theory, we conducted focus group interviews to investigate specific variables that may apply in Malaysian workplaces. Two focus group interviews $(N=13)$ were conducted with two groups of respondents (managers and non-managers) who worked for private and public sector organizations. Data were analysed using a thematic content analysis strategy. The study found that new variables (e.g. organizational politics, bureaucratic factors) emerged as new demands not generally explored in $J D-R$ research, whereas similar demands were identified at a job-task level (e.g. deadlines). Regarding resources these were mainly identified as in other Western research (e.g. support). Job challenge and exploring new things were identified as pleasurable aspects of work. This finding suggests that using qualitative methods is crucial to exploring the psychosocial concept of stress at work to uncover cultural differences that are apparent between Malaysian and Western employees.
\end{abstract}

Keywords: Job demands, job resources, qualitative studies, job stress, JD-R. 


\begin{abstract}
Abstrak
Sejak diperkenalkan pada tahun 2000, model Job Demands and Resources (JD-R) telah banyak diuji di negara Barat. Model ini tidak menentukan secara spesifik pemboleh ubah untuk 'tuntutan kerja' (job demands) dan 'pendorong kerja' (job resources), walaupun beban kerja dan 'deadlines' sering digunakan sebagai pemboleh ubah 'tuntutan kerja', dan 'sokongan" sebagai pemboleh ubah untuk pendorong kerja. Persoalannya, adakah pemboleh ubah yang sering diguna pakai dalam kajian Barat relevan dalam konteks tempatan. Kajian ini, telah dilakukan dengan berpandukan temu duga 'focus group' terhadap dua kelompok $(N=13)$ sampel pekerja. Kajian mendapati pemboleh ubah baru yang tidak pernah muncul dalam kajian $J-D R$ (politik organisasi dan kerenah birokrasi) didapati wujud dalam konteks tuntutan kerja Malaysia, tetapi terdapat persamaan bagi pemboleh ubah tuntutan kerja yang lain (misalnya, sasaran waktu). Bagi pemboleh ubah 'pendorong kerja', didapati tidak terdapat perbezaan dengan konsep Barat. Cabaran kerja dan menerokai teknologi baru pula di tanggap sebagai faktor pekerjaan yang menyenangkan. Kajian merumuskan kaedah kualitatif mampu menerokai kelompangan budaya di antara pekerja di Malaysia daengan negara maju.
\end{abstract}

Kata kunci: Tuntutan kerja, pendorong kerja, kajian kualitatif, tekanan kerja, JD-R.

\title{
Introduction
}

Job characteristics are considered to be important antecedents related to employees' well-being and health (Van den Broeck, Van Ruysseveldt, Smulders \& De Witte, 2010). Although job characteristics emerge as a fashionable topic in the job stress area, Burke (2010) has noted that there are only a few studies on job stress in the developing countries. Most job stress theories are based on the Western perspective (Liu, Spector \& Shi, 2007; Spector, Cooper \& Aguilar-Vafaie, 2002). One of the recent job characteristics stress models arising from the Western tradition is the Job Demands and Resources (JD-R) model (Bakker \& Demerouti, 2007).

The JD-R model introduced two types of job characteristics, namely job demands and job resources. Job demands refer to an employee's responsibility in his or her job, or more simply "things that have to be done" (Schaufeli \& Bakker, 2004, p. 296). Specifically, Bakker, Demerouti and Euwema (2005, pp. 170) have defined job demands as "those physical, social or organizational aspects of the job that require 
sustained physical or mental effort and are therefore associated with certain physiological and psychological costs". On the other hand, job resources can be described as "those physical, psychological, social or organizational aspects of the job" (Schaufeli \& Bakker, 2004, pp. 296) that may energise employee work targets, moderate job demands and intensify personal progression (Bakker \& Demerouti, 2007). While job demands are associated with employee stress, job resources function to boost employee engagement.

While job demands and resources are regarded as important job characteristics, work value is another variable associated with employee job stress. People may value their work for various reasons, such as financial, status or pleasurable aspects of their work environment. Van den Broeck et al. (2010), argue that work value also influences job characteristics, and strengthens the relationship between job characteristics and employee well-being. Kalleberg (1977) has listed six dimensions of work values that are associated with employee satisfaction, including intrinsic components (characteristics of the job itself), convenience (job characteristics that provide creature comforts), financial (such as pay, benefits or security) relationship with co-workers (whether the job permits employees to make friends or friendly co-workers), career (good chance of promotion) and adequacy resources (resources from organisation such as support from the supervisor).

In the current paper, we examined the JD-R model, and in addition we also investigated what the important work values for employees are. So far, the JD-R model has been tested in various occupational settings in many countries. This model has been used for examining employee job stress and well-being in countries such as Germany, Finland, Spain (see Llorens, Bakker, Schaufeli \& Salanova, 2006), and Australia (Lewig, Xanthopoulou, Bakker, Dollard \& Metzer, 2007). However, there are some limitations. For example, nearly all of the studies using the JD-R approach are Western countries, and most of them were derived using English terminology. A problem that sometimes happens when translating English questionnaires is that they could have different meanings for non-native English speakers, or some job characteristics may lead to cultural-specific job stress perception (Liu, Spector \& Shi, 2007). For example, "I love my job' would be normal language usage among English users, but in Spain, the word 'love' refers only to people, not work (Sanchez, Spector \& Cooper, 2006). These limitations can be resolved by using a qualitative approach, which could reveal more and emerging phenomena than a quantitative survey. 
Another limitation is that no study has used a qualitative approach to examine the JD-R model in the Eastern work settings. The previous studies in Western countries could limit an in-depth understanding of the nature of job demands and job resources in developing countries. For example, although work intensity is regarded as part of job demands and leads to job stress in Western contexts, a study by Burke and El-Kot (2009) found something interesting. Their study of Egyptian managers revealed that work intensity not only led to negative outcomes (i.e. job stress), but also predicted positive outcomes (i.e higher job engagement). Given the inconsistent findings between Western and developing countries, the current study used a focus group approach to gain a better understanding of job demands and resources in a Malaysian setting.

We believe that the experiences of employees, and their description, and meaning ascribed to job demands and job resources are crucial since previous research on job stress research discovered that qualitative research sometimes yields different findings from research that focuses only on quantitative data. For example, Liu, Spector and Shi (2007) found that there are differences in results on job stress consequences when comparing qualitative and quantitative methodologies. Similar conclusions have been found by Idris, Dollard and Winefield (2010) using in-depth interview where they found unexpected results from employees' description of their job stress experiences (e.g globalisations as job stressor). Narayanan, Menon and Spector (1999) urged the use of qualitative methodology to get more explicit information about the nature of job stress. Our aim for the current study was to examine how Malaysian employees conceptualize and describe job demands and resources at work. Our study can contribute to the job stress literature in various ways. So far, most job stress studies in Asia are from China or Taiwan (Chang \& Lu, 2007; Lu, Cooper, Kao \& Zhou, 2003). Second, scholars agree that there are differences between collective and individualistic culture that influence how people perceive job-related stress (Duraisingam \& Dollard, 2005; Liu, Nauta, Spector \& Li, 2008). Hopefully, our study will add to the job stress literature, especially in understanding the recent JD-R model and the extent to which it generalises outside the Western context.

\section{What are Job Demand and Resources?}

Although the JD-R model is similar to the Job Demands Control (JDC) model (Karasek, 1979) that emphasizes working characteristics as major factors contributing to employee job stress, the JD-R model is more flexible, and not limited to specific variables (Bakker \& 
Demerouti, 2007). Scholars who introduced the model believe that every occupation has its unique job demands and resources that are closely associated with job stress (Bakker \& Demerouti, 2007). Employee job demands and resources depend on the occupation (Bakker, Hakanen, Demerouti \& Xanthopoulou, 2007) and these may well differ between jobs. However, several variables such as workload, emotional demands, physical demands, work-home interference or organizational change are often used in relation to job demands (Bakker, Demerouti \& Uewema, 2005; Xanthopoulou, Bakker, Demerouti \& Schaufeli, 2007).

The main notion of the JD-R model is that some employees will experience job stress in conditions of high job demands, and low job resources (Bakker \& Demerouti, 2007). While job demands can adversely affect employees' health, resulting in burnout, job resources play a crucial role in boosting their motivation, through engagement (Schaufeli \& Bakker, 2010). With the recent increasing use of the JD-R model among job stress scholars (Demerouti, Bakker, Nachreiner \& Schaufeli, 2001; Lewig et al., 2007; Llorens et al., 2006), the question is whether the common variables in the JD-R model that had their origins in Western formulations are applicable in developing countries. For example, while job control is regarded as job resource in most JD-R studies it is apparently not important in some cultures such as in China (see Nauta, Liu \& Li, 2010), and certain aspects of job demands could be perceived differently for employees outside the Western context (Burke \& El-Kot, 2010). Due to such inconsistencies, Duraisingam and Dollard (2005) for example, urged for the need to find out specific job demand and job resource variables for developing countries.

\section{Method}

\section{Design}

In this study, we used focus groups. The advantage of using this method is that it allows the researcher to gain insights into people's knowledge and their employment experiences. For these reasons, this study used qualitative data, based on the focus group method to discover and gauge employees' own experiences of the demands and resources in their workplace.

\section{Participants}

Samples were chosen through purposive and professional networking (see Idris, Dollard \& Winefield 2010; Kinman \& Jones, 
2005). Participants were selected from various organisations that represented a wide range of businesses and occupations. To ensure that our research sampling represented a range of occupations, we tried to contact as many participants as possible, from different organisations (i.e. oil and gas, manufacturing, media, university, school, hospital, construction, services etc). Thirty-five respondents were first approached by phone, and if available, were then contacted via e-mail to brief them about the research. In some cases, if the contacted respondents were unable to participate, we also asked them if they could suggest work colleagues or others who were in a similar position to them. We also asked them whether they worked in managerial or non-managerial positions. From the 35 people contacted, only 20 were willing to participate in our study. However, on the date when the focus group sessions were conducted, only 13 participants attended the sessions. We considered the nature of power distance (Hofstede, 1994) in the Malaysian workplace that may impede interaction between managers' and non-managers' discussions. Therefore, we used separate focus groups consisting of people at the managerial level and the non-managerial level. The separation between the groups could enhance our understanding of the similarities and differences in the perceptions of demands and resources between the employees who are involved in managerial tasks and non-managerial duties. Two focus groups were formed; managerial level $(N=6)$ and non-managerial level $(N=7)$ who worked in various occupations.

\section{Procedure}

Each focus group discussion was facilitated by a group leader (i.e. research assistant) and the discussion lasted approximately 180 minutes for the manager group, while the non-manager group's discussion lasted 150 minutes. Both discussions were recorded with the participants' consent. At the beginning of each session, the moderator briefed the groups about the reasons for the study, and group members were encouraged to express their opinions freely about their experiences, knowledge and any related issues about their jobs. Participant information forms were also distributed to them to explain the nature of the focus group and the aims of the study. When all participants agreed to participate in the research, the consent forms were disseminated to all participants. The moderator's role was to encourage special issues that occurred during the session, or monitor any unnecessary dialogue that may have risen. After discussion, each group member received a nominal fee, and group leaders expressed their appreciation for their participation. 
The discussions were conducted in the Malay language. The questions asked were as follows:

1. What are the most helpful things that ensure your job runs effectively or smoothly?

2. Would you say that these factors represent 'job resources'?

3. What are the factors at work that make you feel stressed?

4. Would you say these factors represent 'job demands' or simply the most demanding aspects of your job?

5. What are the most pleasurable aspects of your work?

We also had a problem in translating some terminology in the current research. Given the lack of a formal translation for the terms 'job demands' and 'job resources' in the Malay language, in the current study we interchangeably used Malay and English when discussing a term with the participants. We explained to them the closest equivalents of 'job demands' and 'job resources'. In general, we used 'tuntutan pekerjaan' for job demands. For job resources, we used either 'pendorong pekerjaan' or 'penggalak pekerjaan' both of which represent a close meaning to 'job resources'.

\section{Analysis Strategy}

Coding themes in our analysis were based on themes that had been published in previous JD-R studies (Bakker, Demerouti, de Boer \& Schaufeli, 2003; Bakker et al., 2005; Bakker, Demerouti \& Schaufeli, 2003; Bakker, Demerouti, Taris, Schaufeli \& Schreurs, 2003; Bakker et al. 2007; Demerouti et al., 2000; Demerouti et al., 2001; Hakanen, Bakker \& Demerouti, 2005; Hakanen, Bakker \& Schaufeli, 2006; Llorens et al., 2006; Mauno, Kinnunen \& Ruokolainen, 2007; Schaufeli, \& Bakker, 2004; Xanthopoulou et al., 2007). We first transcribed interviews verbatim from tape recordings. A content analysis was conducted to identify the main themes that emerged during the interviews (Kinman \& Jones, 2005). Data analysis was performed by the first author. Standards of analysis were used in accordance with Kvale (1996): to avoid bias in the interpretation of data, we engaged another scholar who was familiar with job stress in Malaysia to validate our analysis. Following separate analyses, themes were matched and in case of any disagreement between the themes arising, the first author made an adjustment to ensure that there was consensus on themes.

Using this method, we categorised job demads and resources themes as they emerged in our study. However, we created new themes for those arising in our analysis but not occurring in previous JD-R studies. 


\section{Results and Discussion}

\section{What are Job Demands for Malaysian Employees?}

Although employees may describe their work experiences and nature of job stress from their own perspectives (Kinman \& Jones, 2005), at the first level of analysis, our focus group participants revealed that job demands were conceived similarly among Malaysian employees as the were in the West. In general, most participants highlighted the familiar job demads variables discussed in the Western literature. This could reflect the idea that globalisation and the changing nature of work have influenced employees in their work settings in both developed and developing countries (Sauter \& Murphy, 2003).

As illustrated in Table 1, from a total of 69 statements recorded for our analysis, we found that deadlines are described as the most common job demand in the workplace (12 statements). One publishing company worker said: "In my field, the most stressful part in my job is the deadline. Deadline is the word that is always said by my boss by hook or by crook' I must finish my tasks". Similarly another respondent who worked as a newspaper reporter said: "As I have finished my assignment [field work], then within 1 hour I must complete my story. Then we have a meeting to discuss tomorrow's deadline, but at the same time I also need to make amendments to my current story as suggested in the meeting. Then my boss pushes for pictures to be inserted. Deadlines again. I face a similar process on every work day". Another respondent who worked in the construction sector said: "In my job, we always try to compete with tender jobs. Although we know the submission date exactly, sometimes it will not always happen. For example, during the last month, we were informed only one day before the deadline for tender submission".

Interestingly, organizational politics emerged in our analysis as a job demand. Some previous JD-R studies have not included organizational politics in their investigations. One respondent stressed his opinion: "What I see, in Malaysia [workplaces] now is very political. Peer politics. This is very annoying. When you meet someone at certain events, they will ask you, 'how is your [organizational] politics?" Because organizational politics are sometimes perceived as unfair threats to employees (Ferris \& Kachmar, 1992; Vigoda, 2002), respondents also mentioned this situation in their organization. One female manager indicated: "What I experienced, when someone [from a particular ethnic background] was appointed as a manager, they will favour their own ethnic group employees rather than others. Even if their subordinates [from the same ethnic group] failed to complete tasks, that is still okay". Another respondent shared

142 IJMS 18 (1), 135-154 (2011) 
this experience in the workplace: "In the past, when I worked for one company owned by [ethnicity], I think I have learned more. But when I worked for [another ethnicity], I think they play a lot of political games. Before I could go to bed and sleep easily, but now I have problems [thinking about organizational politics]'.

Table 1

Job Demands at Work

\begin{tabular}{lc}
\hline Demands & Number of Statements \\
\hline Deadlines & 12 \\
Organizational politics & 6 \\
Bureaucracy /red tape & 5 \\
Expectations of others & 5 \\
Little support & 5 \\
Dealing with clients/customers & 4 \\
Workload & 4 \\
Little feedback & 3 \\
Role conflict & 3 \\
Unclear goals & 3 \\
Fast pace & 2 \\
Job security & 2 \\
Dealing with difficult people & 2 \\
Problems with tools/information technology & 2 \\
Organizational culture & 2 \\
New performance system & 1 \\
Supervision/leadership & 1 \\
Communication problems & 1 \\
Others & 69 \\
Individual factors/personality & 1 \\
Work-family conflicts & \\
Lack of recognition & 6 \\
\hline Total & 1 \\
\hline
\end{tabular}

Respondents also mentioned that bureaucratic issues are part of the demands of their job. So far, in our review of the most recent Western articles that focused on the JD-R model, this aspect was not reported (Bakker et al., 2003; Bakker et al., 2005; Bakker, Demerouti \& Schaufeli, 2003; Bakker et al., 2003; Bakker et al., 2007; Demerouti et al., 2000; Demerouti et al., 2001; Hakanen et al., 2005; Hakanen et al., 2006; Llorens et al., 2006; Mauno et al., 2007; Schaufeli \& Bakker, 2004;

IJMS 18 (1), 135-154 (2011) 143 
Xanthopoulou et al., 2007). One officer who worked for a government agency noted: "For me, all of these [bureaucratic issues] are part of my job demands. I can't distance myself from these because the government has many policies and departments. I'm lucky because I work in a technical department. If not, I'm sure that I could face a lot of these hindrances". One manager who worked in one public sector department stressed: "I agree that stress occurs in all work places. However, in the government agencies, we can't say that because their system [bureaucratic] is bad; we have the option to choose another system. In fact, the system is there and was decided by policy makers. Whether we feel stressed or not, we need to face this fact. What we can do only is to adapt to the stress".

Bureaucratic problems not only occurred in the public sector but in the private sector as well. One manager who worked for a multinational firm said: "Bureaucratic issues are a problem in organizations. A very simple thing sometimes becomes complicated because of bureaucracy and red tape. It is unnecessary stress and leads to real stress".

Another important aspect that was perceived as a job demand was the level of expectation of others, whether from one's supervisor, co-workers or subordinates. One female manager expressed this opinion: "Sometimes we feel trapped by other people's expectations. We may have performed our work well but we wonder if we have done the right thing". Another manager shared his experience of when he had worked abroad: "When I was in Germany as a project leader, and worked with some workers from Italy and France, all of them reported to me. I felt stress about whether I could perform". Another respondent remarked: "As a manager, I have superiors and sub-ordinates. I feel stress about what my supervisor's expectations are, and at the same time I am also thinking about my subordinates' expectations".

Low or little support also emerged in our study. One respondent said: "To accomplish tasks we actually need support from others. But if we have a problem with support, I think we will fail to deliver the tasks". In such cases, low levels of support combined with lack of recognition created more complicated working conditions. For example, one respondent remarked about her experience at work: "I feel stressed when other people don't want to appreciate our work. Of course, I don't expect their nice words. Yet sometimes they criticize my work. They don't want to share their experiences and knowledge. That makes me feel unmotivated".

Other demands reported in our study include workload and dealing with clients/customers. These particular aspects have been discussed extensively in previous studies (Bakker et al., 2003). In conclusion, job demands as described by our respondents are more associated

144 IJMS 18 (1), 135-154 (2011) 
with the work context and group dynamics in the workplace. Unlike deadlines and support, organizational politics, other people's expectations and bureaucracy have rarely been discussed in previous research using the JD-R model. However, scholars of job stress have found that organizational politics and bureaucracy are associated with poor performance among employees (Wallace, Edwards, Arnold, Frazier \& Finch, 2009) and act as stressors in the workplace (Vigoda, $2000,2002)$. In combination they were identified as hindrance stressor problems (e.g. Wallace et al., 2009).

\section{Job Resources: How Were They Perceived?}

Job resources play important roles in energising employees' motivation. As indicated in Table 2, our analysis found that the most important job resource among the respondents was related to social support. From a total of 36 statements made, 12 statements discussed the importance of social support.

One respondent expressed his opinion about the importance of support: "The manager is actually a middleman. We get directions from the top management; we pass it on to the sub-ordinates. If we don't have enough support, we can get nothing done". Another respondent said: "Even if we have a strong information technology system, if we don't have support from others; we are unable to perform effectively. Both advanced systems and team work complement each other". One female worker remarked: "As a publication worker, the most important things that make my job run smoothly are that I have a group of supportive people, a good editor, an excellent publisher, and an artist who delivers on time. If all of them could not meet deadlines, it would make my job much harder".

Table 2

Job Resources at Work

\begin{tabular}{lc}
\hline Job Resources & Number of Statements \\
\hline Social support & 12 \\
Knowledge & 4 \\
Management quality & 4 \\
Information communication technology & 3 \\
Experience & 2 \\
Networking & 2 \\
\hline & (continued)
\end{tabular}

IJMS 18 (1), 135-154 (2011) 


\begin{tabular}{lc}
\hline Job Resources & Number of Statements \\
\hline Finance/salary & 2 \\
Family & 2 \\
Job control/Autonomy & 1 \\
Clear goals & 1 \\
Career development & 1 \\
Feedback & 1 \\
Love own job & 1 \\
Religious & 1 \\
\hline Total & 37 \\
\hline
\end{tabular}

Besides the importance of support, management quality also played a crucial role as a job resource. One respondent made the following statement: "I can perform work well ifI work in a well organized environment. I can do my job if no one disturbs me. Sometimes my job is interrupted by subordinates, sometimes by superiors. So, I think management should ensure everything is well organised." Another respondent indicated: "Everything must be in order. The system must operate in an appropriate way, authority, workflow, guidelines, and team work and so on." In the modern workplace, information technologies have been emphasised as a crucial aspect of work. One respondent indicated that: "In the current working environment, we are no longer depending on old filing systems. We need a current information technology system." Another respondent expressed the need for information technologies as part of work in an increasingly competitive world. He said: "For me, to ensure that I am up-to-date with the knowledge, I must obtain help from people who work on websites. This helps me to improve my job". One tutor who worked at a university expressed her opinion: "I' $m$ very particular about computer facilities. I am very demanding regarding the latest technology. If it is not provided, it will make me stressed."

Interestingly, although some previous JD-R studies emphasised job control as part of job resources, this study found that Malaysian employees did not mention this variable as much as Western workers did. In our recent study (Idris, Dollard \& Winefield, 2010), we also found a similar trend when Malaysian respondents did not draw attention to this theme. We can assume that in a collective society where the power distance (Hofstede, 1994) is very wide between the executives and the employees, people might not be concerned about exerting control over their own jobs.

146 IJMS 18 (1), 135-154 (2011) 
In conclusion, we found both similarities and differences regarding job demands and resources perceived by Malaysian employees as compared to Western employees. We found that, while some job demands are coherent with the JD-R model (i.e. deadlines), Malaysian employees also identify some job demands not referred to in previous Western studies (i.e. organisation politics). We found however, that for job resource variables, there were not many differences from the Western literature. Our findings could imply that each country has its own unique job characteristics, and not all conform to the Western stereotype.

\section{Workplace is Not Only an Evil. What Did They Say?}

Jobs do not always create problems for employees, but work also has meaning for employees (Van den Broeck et al., 2010). In this study, participants described various aspects that might be valuable for them. As indicated in Table 3, job challenges and exploring new things were reported as beautiful things at work. One respondent described his experience as follows "For me, if we feel engaged with our job, we are no longer concerned with the financial aspect, or benefits. The most important things are to prove our potential. I am even able to deal with a big project alone...". Another participant said: "For me, I am very excited if I can achieve my work target... able to complete my task within a deadline". One newspaper reporter told his experience: "For me, although I know that my job is very demanding, sometimes I need to work until midnight. Sometimes my supervisor calls me to meet someone, although we know that person might be sleeping at that time. Sometime, he asks me to find a story at 10:00 pm, and the deadline is at $12 o^{\prime}$ clock at midnight. But, if I am able to achieve a target, it is very amazing for me."

Exploring new things is also described as one of the pleasurable experiences in the workplace. One manager said: 'Before this I worked in the Accounting Department, and then I moved to the Information Technology section. Although I found it difficult the first time, now I feel happy to get new knowledge'. Another respondent, said: "I worked for a private company. Before this I worked as a planner, but now as a QS (Quantity Surveyor). I feel sometimes going to work is like going to school. We are able to learn new things, share experiences with a new boss. For me, this is a great thing that I have gained from the work."

Internal satisfaction or attachment to the job was also one of the important factors that made employees feel happy with their jobs. One participant said: "For me, people feel engaged with their jobs because they get satisfaction from their jobs. For example, teachers...if they work because of money, they only deliver what is described in their job description. 
But, if they have interest in their job...feel responsible...I think this is the best way." Another participant said: "If you ask me what is pleasurable..I have already worked for more than 10 years. I recognised that...I love this job. I feel engaged and more responsible. Every time, when I am preparing to go home...I think what I should do tomorrow. That's why I have never changed my job."

Table 3

Pleasurable Aspects at Work

\begin{tabular}{lc}
\hline Pleasurable aspects at work & Number of Statements \\
\hline Job challenging & 11 \\
Explore new things & 10 \\
Internal satisfaction & 8 \\
Financial & 7 \\
Appreciation by others & 5 \\
Job control & 3 \\
Conducive working environment & 3 \\
\hline Total & 47 \\
\hline
\end{tabular}

Financial benefits were also acknowledged as one of the pleasurable things in the workplace. One participant, clearly indicated: "The first thing...the rule of thumb...is money." Another participant gave a good example of how money motivated people at work. She said: "I think financial reward is important. If you ask the fresh graduates who are currently working, whether they are happy or not...I think they will say that they are not happy. This is because what they want is only money. They are driven by money. Pleasure will only come after they are satisfied with their financial income."

Participants also stressed the importance of appreciation of others as part of job pleasure. One respondent said: "Once we deliver our job, and my boss is happy and satisfied with what I have done...for me, this is pleasurable."

\section{Conclusion}

Our study found that deadlines, organizational politics and bureaucratic issues are typical job demands of the Malaysian workplace. Achieving a deadline is a common job demand for every modern workplace in both developed countries and developing 
countries. However, organizational politics and bureaucratic issues have not been discussed in depth, if at all, by scholars who use the JD-R model as their framework for studying job stress.

In Malaysia's context, organizational politics has an impact on job stress as has been demonstrated in previous research (Poon, 2003). At the international level, Vigoda (2002) for example, has summarised the association between organizational politics and negative emotions in the workplace (job anxiety, job stress, job tension) and organizational politics has a positive relationship with these domains. Job stress also emerged as a mediator between organizational politics and aggressive behaviour in the workplace. However, since organizational politics has still not been extensively examined from the JD-R perspective, our study is a preliminary study that requires further investigation

Bureaucracy also emerged in our study. Since our study did not focus on the antecedents of these particular issues, we do not really know what factors have contributed to this situation. However, since Malaysia is a country that well demonstrates power distance and social collectiveness (Hofstede, 1994), we can assume that these factors have also indirectly contributed to bureaucracy and 'red tape' in Malaysian workplaces. In a recent study, Wallace et al. (2009) found that bureaucracy and red tape caused problems regarding organizational performance.

We see that job demands and working conditions have cultural implications. Most common job stressors as reported in Western literature (i.e. deadlines, workload) are always regarded as major contributors to employees' strain (Karasek, 1979). However, the current study found that Malaysian employees have a different perception on factors that contribute to their stress, such as organizational politics and bureaucracy that occur in the workplace. Although scholars are agreed that organisational politics and bureaucracy could lead to job stress (Poon, 2003; Vigoda, 2002; Wallace et al., 2009) and affect employees' performance, so far these factors have not been studied in the JD-R framework. Our findings which suggest that different cultures and countries have their own specific perceptions of what is regarded as a workplace stressor (Glazer \& Gyurak, 2008; Lu, Seng \& Cooper, 1999), could provide insight into working conditions in Muslim developing countries. For example, while favouritism is something that is unacceptable in the Western workplace, in some developing countries and collective cultures, favouritism is regarded as a normal practice (Ali, 2010). 
Participants also perceive their jobs in several ways. Being an employed worker confronted them with challenges, learn new things and satisfy their internal needs. Thus, we see that although employees described several factors that contributed to job stress (i.e. job demands), and aspects that buffer the impact of job demands (i.e. job resources), employees also indicated the aspect of their jobs that related to their needs.

\section{Limitations}

Although using a qualitative study enhances our understanding of employees' experience of job stress, some limitations should be acknowledged. The current study only utilized a small group of participants (e.g. two groups) comprising managerial and nonmanagerial staff. We also only covered a few types of occupations. It would have been better if the study had used more participants, as well as a greater range of occupations. We found it difficult to get more participants to participate in the study as in Malay culture, people are not too willing to express their problems due to 'malu' or 'ashamed personality' (Goddard, 1996). However, Berland, Natvig and Giunderson (2008) only used a small number of participants and nonetheless found that they were able to describe the nature of job stress.

We also had a problem in translating some terminology in the current research. So far, no study using the JD-R model has been conducted in Malaysia. Job resources when translated into the Malay language (sumber pekerjaan), does not reflect job resources as defined in Western terminology. A very close meaning for 'job resources' in Malay terminology is 'job support' or 'sokongan pekerjaan'. Job support however has a different meaning. Due to the fact that there are no exact words to explain the job resources, in the current study, first we explained to the participants how we define 'job resources'. We gave them a few examples before discussing their attitudes to job resources.

\section{Future Research}

Future research should use a large sample in order to enhance the external validity of the findings. Researchers should also consider testing factors associated with job demands and resources by using a different methodology (i.e. survey). The effects of deadlines, organizational politics or social support on employees' psychological health erosion (i.e. burnout) or motivational pathways (i.e. work engagement) as proposed by the JD-R model (Bakker \& Demerouti, 
2004) may contribute to better explanations. In addition, using a comparison study with other cultures or countries would also be helpful to determine whether any boundary conditions limited the current findings.

\section{References}

Ali, A. J. (2010). Islamic challenge to HR in modern organizations. Personnel Review, 39, 692-711.

Bakker, A. B., \& Demerouti, E. (2007). The job demands-resources model: State of the art. Journal of Managerial Psychology, 22, 309328.

Bakker, A. B., Demerouti, E., de Boer, E., \& Schaufeli, W. B. (2003). Job demands and job resources as predictors of absence duration and frequency. Journal of Vocational Behavior, 62, 341-356.

Bakker, A. B., Demerouti, E., \& Euwema, M. C. (2005). Job resources buffer the impact of job demands on burnout. Journal of Occupational Health Psychology, 10, 170-180.

Bakker, A. B., Demerouti, E., \& Schaufeli, W. B. (2003). Dual processes at work in a call centre: An application of the job demandsresources model. European Journal of Work and Organizational Psychology, 12, 393-417.

Bakker, A. B., Demerouti, E., Taris, T. W., Schaufeli, W. B., \& Schreurs, P. J. G. (2003). A multigroup analysis of the job demandsresources model in four home care organizations. International Journal of Stress Management, 10, 16-38.

Bakker, A. B., Demerouti, E., \& Verbeke, W. (2004). Using the job demands-resources model to predict burnout and performance. Human Resource Management, 43, 83-104.

Bakker, A. B., Hakanen, J. J., Demerouti, E., \& Xanthopoulou, D. (2007). Job resources boost work engagement, particularly when job demands are high. Journal of Educational Psychology, 99, 274-284.

Berland A, Natvig G. K., \& Gundersen, D. (2007). Patient safety and job-related stress: A focus group study. Intensive and Critical Care Nursing, 24, 90-97.

Burke, R. J. (2010). Workplace stress and well-being across cultures: research and practice. Cross Cultural Management: An International Journal, 17, 5-9.

Burke, R. J., \& El-Kot, G. (2009). Work intensity, work hours, satisfactions, and psychological well-being among Egyptian managers. Education, Business and Society: Contemporary Middle Eastern Issues, 2, 218-231 
Chang, K., \& Lu, L. (2007). Characteristics of organizational culture, stressors and wellbeing: The case of Taiwanese organizations. Journal of Managerial Psychology, 22, 549-568.

Demerouti, E., Bakker, A. B., Nachreiner, F., \& Schaufeli, W. B. (2000). A model of burnout and life satisfaction amongst nurses. Journal of Advanced Nursing, 32, 454-464.

Demerouti, E., Bakker, A. B., Nachreiner, F., \& Schaufeli, W. B. (2001). The job demands-resources model of burnout. Journal of Applied Psychology, 86, 499-512.

Duraisingam, V., \& Dollard, M. F. (2005). The management of psychosocial risk factors amongst rural development workers in India. International Journal of Rural Management, 1, 97-123.

Ferris, G. R., \& Kachmar, K. M. (1992). Perceptions of organizational politics. Journal of Management, 18, 93-116.

Fiksenbaum, L., Jeng, W., Koyuncu, M., \& Burke, R. J. (2010). Work hours, work intensity, satisfactions and psychological well-being among hotel managers in China. Cross Cultural Management: An International Journal, 17, 79-93.

Glazer, S., \& Gyurak, A. (2008). Sources of occupational stress among nurses in five countries. International Journal of Intercultural Relations, 32, 49-66.

Goddard, C. (1996). The 'social emotions' of Malay (Bahasa Melayu). Ethos, 24, 426-464.

Hakanen, J. J., Bakker, A. B., \& Demerouti, E. (2005). How dentists cope with their job demands and stay engaged: The moderating role of job resources. European Journal of Oral Sciences, 113, 479-487.

Hakanen, J. J., Bakker, A. B., \& Schaufeli, W. B. (2006). Burnout and work engagement among teachers. Journal of School Psychology, 43, 495-513.

Hofstede, G. (1994). Cultures and organizations. London: Harper Collins Publishers.

Idris, M., Dollard, M. F., \& Winefield, A. H. (2010). Lay theory explanation of occupational stress: The Malaysian context. Cross Cultural Management: An International Journal, 17, 135-153.

Kalleberg, A.L. (1977). Work values and job rewards: A theory of job satisfaction. American Sociological Review, 42, 124-143.

Karasek, R., Brisson, C., Kawakami, N., Houtman, I., Bongers, P., \& Amick, B. (1998). The job content questionnaire (JCQ): An instrument for internationally comparative assessments of psychosocial job characteristics. Journal of Occupational Health Psychology, 3, 322-355.

Karasek, R. A., Jr. (1979). Job demands, job decision latitude, and mental strain: Implications for job redesign. Administrative Science Quarterly, 24, 285-308. 
Kinman, G., \& Jones, F. (2005). Lay representations of workplace stress: What do people really mean when they say they are stressed? Work and Stress, 19, 101-120.

Kvale, S. (1996). Interview: An introduction to qualitative research interviewing. London: Sage Publication.

Lewig, K. A., Xanthopoulou, D., Bakker, A. B., Dollard, M. F., \& Metzer, J. C. (2007). Burnout and connectedness among Australian volunteers: A test of the job demands-resources model. Journal of Vocational Behavior, 71, 429-445.

Liu, C., Nauta, M.M., Spector, P.E., \& Li, C. (2008). Direct and indirect conflicts at work in China and the US: A cross-cultural comparison. Work and Stress, 22, 295-313.

Liu, C., Spector. P.E., \& Shi, L. (2007). Cross-national job stress: A quantitative and qualitative study. Journal of Organizational Behavior, 28, 209-239

Llorens, S., Bakker, A. B., Schaufeli, W., \& Salanova, M. (2006). Testing the robustness of the job demands-resources model. International Journal of Stress Management, 13, 378-391.

Lu, L., Tseng, H., \& Cooper, C. L. (1999). Managerial stress, job satisfaction, and health in Taiwan. Stress Medicine, 15, 53-64.

Lu, L., Cooper, C. L., Kao, S. F., \& Zhou, Y. (2003). Work stress, control beliefs and well-being in Greater China: An exploration of subcultural differences between the PRC and Taiwan. Journal of Managerial Psychology, 18, 479-510.

Mauno, S., Kinnunen, U., \& Ruokolainen, M. (2007). Job demands and resources as antecedents of work engagement: A longitudinal study. Journal of Vocational Behavior, 70, 149-171.

Narayanan, L., Menon, S., \& Spector, P. E. (1999). Stress in the workplace: A comparison of gender and occupations. Journal of Organizational Behavior, 20, 63-73.

Poon, J.M.L. (2003). Situational antecedents and outcomes of organizational politics perceptions. Journal of Managerial Psychology, 18, 138-155.

Sanchez , J. I., Spector, P.E., \& Cooper, C. L. (2006). Frequently ignored methodological issues in cross-cultural stress research. In T. P Wong Paul, \& L. J. Wong Lilian (Eds), Handbook of Multicultural perspectives on stress and cooping. Springer Science Business Media Inc, USA.

Sauter, S., \& Murphy, L. (2003). Monitoring the changing organization of work: International practices and new developments in the United States. Social and Preventive Medicine, 48(6), 341-348.

Schaufeli, W. B., \& Bakker, A. B. (2004). Job demands, job resources, and their relationship with burnout and engagement: A multisample study. Journal of Organizational Behavior, 25, 293-315. 
Schaufeli, W. B., \& Bakker, A. B. (2010).Defining and measuring work engagement: Bringing clarity to the concept. In A. B Bakker, \& M. P. Leiter (Eds.), Work engagement: A handbook of essential theory and research (pp. 10-24). East Sussex: Psychology Press.

Spector, P. E., Cooper, C. L., \& Aguilar-Vafaie, M. E. (2002). A comparative study of perceived job stressor sources and job strain in American and Iranian managers. Applied Psychology: An International Review, 51, 446-457.

Van den Broeck, A., Van Ruysseveldt, J., Smulders, P., \& De Witte, H. (2010). Does an intrinsic work value orientation strengthen the impact of job resources? A perspective from the job demandsresources model. European Journal of Work and Organizational Psychology, 1-28

Vigoda, E. (2000). Organizational politics, job attitudes, and work outcomes: Exploration and implications for the public sector. Journal of Vocational Behavior, 57, 326-347.

Vigoda, E. (2002). Stress-related aftermaths to workplace politics: The relationships among politics, job distress, and aggressive behavior in organizations. Journal of Organizational Behavior, 23, 571-591.

Wallace, J. C., Edwards, B. D., Arnold, T., Frazier, M. L., \& Finch, D. M. (2009). Work stressors, role-based performance, and the moderating influence of organizational support. Journal of Applied Psychology, 94, 254-262.

Xanthopoulou, D., Bakker, A. B., Demerouti, E., \& Schaufeli, W. B. (2007). The role of personal resources in the job demandsresources model. International Journal of Stress Management, 14, 121-141.

Xanthopoulou, D., Bakker, A. B., Dollard, M. F., Demerouti, E., Schaufeli, W. B., Taris, T. W., et al. (2007). When do job demands particularly predict burnout? The moderating role of job resources. Journal of Managerial Psychology, 22, 766-786. 